\title{
State Aid and Taxation of Transnational Companies: A Study of State-Corporate Crime
}

\author{
Nubia Evertsson ${ }^{1}$ (D)
}

Published online: 30 September 2017

(C) The Author(s) 2017. This article is an open access publication

\begin{abstract}
This study examines the taxation of transnational companies from the perspective of state-corporate crime. As in Sutherland's pioneering study on white-collar crime, the author relies, in this case, on administrative decisions issued by the European Commissioner for Competition regarding Fiat and Starbucks. According to the Commissioner, the tax advisors of these organizations prepared and submitted special tax rulings on behalf of their clients that were granted by the Luxembourg and Dutch tax authorities, respectively. However, these tax rulings were considered illegal under European law, as they constitute state aid. Therefore, the Commissioner fined Fiat and Starbucks. In this inquiry, state aid from tax rulings is conceived as a process of capital accumulation that arises from states' regimes of permission based on the interactions between public sector and private sector actors. Thus, an observable symbiosis between tax authorities and transnational companies allowed the latter to use tax regulations in a manipulative way, while the former exercised weak/undue control. This study also unveiled the criminogenic role of tax advisors, an industry that is rarely held accountable for their actions.
\end{abstract}

\section{Introduction}

Article 107, No. 3 of the Treaty on the Functioning of the European Union prescribes that a member state can give aid to corporations promoting economic activities, projects of common European interest, and projects of cultural and heritage conservation. However, state aid cannot be granted to distort competition within the internal market (Article 107, No. 1). The European Commissioner for Competition is the authority responsible for enforcing this legislation. During recent years, Commissioner Margrethe Vestager has opened various investigations against transnational companies (TNC) operating in

Nubia Evertsson

nubia.evertsson@criminology.su.se

1 Department of Criminology, Stockholm University, Universitetsvägen 10C, 10691 Stockholm, Sweden 
European territories for receiving state aid through favorable tax rulings. Some of the companies under investigation include Starbucks, Fiat, Apple, Amazon, McDonald's, and Engie. In the first three cases, the investigations have been concluded, and the Commissioner fined the companies and ordered the tax authorities to recover the illegal aid they were granted. This study examines the cases of Starbucks and Fiat.

Herein, the taxation of TNC is considered a process of capital accumulation despite that it is not usually classified as such. This critical approach seeks to establish evidence that the taxation of this type of corporation is the result of agreements between public sector and private sector actors that only benefit TNC. These agreements have been enacted not only at the national level but also at the international level. For example, the Organization for Economic Co-operation and Development (OECD) transfer price guidelines are used as referents in the taxation of TNC. These guidelines aim to avoid double taxation of TNC by introducing direct and indirect methods to estimate costs that affect the national taxable bases. Conflicts emerge when TNC use these guidelines in a manipulative way and national tax authorities approve it, even though this is contrary to international frameworks. By taking a state-corporate approach, this study aims to demonstrate that nation states promote the capital accumulation of TNC by violating international legal frameworks as well as their own interests.

This manuscript is structured as follows. In the first section, the state-corporate crime theory is presented and discussed taking into consideration the critiques and developments introduced by scholars in the field. The second section presents the principal studies that explore the relationships and existing symbioses observed between states and corporations. The third section describes the cases of Starbucks and Fiat. In particular, the subsidiaries involved in the investigation, the tax rulings granted by the Netherlands and Luxembourg authorities, the main evidence collected by the Commissioner, and the final decisions and sanctions imposed are discussed. The fourth section analyzes the cases studied in light of the state-corporate crime theoretical developments and the principal research in the field. The last section concludes the paper.

\section{State-Corporate Crime}

Raymond J. Michalowski and Ronald C. Kramer introduced the concept of state-corporate crime to explain 'how corporations and governments intersect to produce social harm' (Kramer et al. 2002: 263). They argue that state-corporate crime emerges when powerful corporations shape laws, regulations, and the market in the context of emergent globalization. In their pioneering study, Michalowski and Kramer (1987) examined the expansion of TNC in the third world and noted that TNC engage in transgressions in host countries. According to Michalowski and Kramer (1987: 47), the study of transgressions overcomes the relativism of the term crime as crime is only associated with violations of the law. They further noted that the term transgression facilitates the identification of deviant behaviors, of violations of international standards of corporate conduct, and of the use of accepted economic practices that result in social and individual injuries. Some of the transgressions earlier studied by Michalowski and Kramer (1987) address unsafe and unhealthy work conditions of TNC that operate in developing countries, the relocation of highly polluted industries in the global south, and the lack of information that endangers consumer safety internationally. Later, Kramer (1992) used the concept of state-corporate crime to study the transgressions of large companies that operate within the country of incorporation. His 
landmark study on the explosion of the space shuttle Challenger illustrated the damages and injuries that emerged from the harmful interactions between the American Corporation Morton Thiokol Inc. and the National Aeronautics and Space Administration (NASA).

Kramer et al. (2002: 279) claimed that the deviant behavior of business leaders and government officials should not only be understood as harmful internal practices adopted by private corporations but should also be understood as the result of the relationship between state and corporate actors. By taking this approach, they extended the analysis of corporate crimes beyond the borders of the organization, explaining that state-corporate crime deals.

with the political and economic processes that enable state and corporate managers to pursue plans and policies - often in concert with one another - that result in death, injury, ill health, financial loss, and increasingly in the globalized capitalist economy, cultural destruction, all the while being insulated from the full weight of criminalization for these actions (Kramer et al. 2002: 266).

These scholars distinguished two forms of deviant relationships that emerge from the interaction between state agencies and corporations. State-initiated corporate crime includes corporate transgressions that are directed or tacit approved by a government agency. State-facilitated corporate crime includes corporate transgressions that emerge when governments fail to control deviant business activities because of collusion between state officials and business leaders or because of the use of aggressive regulations that facilitate the adherence to shared goals (Kramer et al. 2002: 271).

Although [critical] criminologists acknowledge the contributions of the concept of statecorporate crime to understand this form of transgression, they have also noted certain limitations. One often-discussed issue involves the various forms "in which states either facilitate or engage in criminal activity" (Kauzlarich et al. 2003: 251). In this respect, Kauzlarich et al. (2003: 248-250) noted that in the main body of available literature, categories of state-corporate crime, namely, state-initiated and state-facilitated corporate crime, emerge from the tacit approval of governmental agencies and from actions or inaction by governmental agencies, respectively. This perspective suggests that state involvement in crime is largely regarded as a monolithic construct. These scholars challenged this conventional approach by introducing the concept of a complicity continuum, with the objective of developing a new etiology of state crime based on the degree of involvement of the state in criminal practices. Thus, Kauzlarich et al. (2003) added to the original nomenclature a classification that distinguishes actions by the state as either explicit and implicit acts of commission (purposeful actions) or explicit and implicit acts of omission (negligent actions). Furthermore, they noted that such actions of the state 'may result in multiple forms of state crime at any one particular time, and perhaps even simultaneously' (Kauzlarich et al. 2003: 251).

Another issue discussed in the literature focuses on the actors involved in this type of crime. Friedrichs and Rothe (2014), who have suggested that more clarity is needed to elucidate the preponderance of the actors involved in these types of crime, proposed to reorder the basic nomenclature to indicate the initiator of this type of crime. Specifically, they suggested that the term state-corporate crime should be used when the initiator is a state and the term corporate-state crime be used when the initiator is a corporation. Friedrichs and Rothe (2014) have also expressed concern regarding the profiles of actors involved in state-corporate crime and these actors' relationships. With respect to the actors, Friedrichs and Rothe (2014) have argued that it is important to define precisely the terms state and corporation. They further noted that it is problematic that the first term, i.e., state, 
includes both governments and citizens, while the second term, i.e., corporation, excludes transnational actors that operate on a global scale. To address this issue, Friedrichs and Rothe (2014) propose to constrain the analysis of the state to government officials while including the analysis of other types of organizations, such as international financial organizations, large scale investment and commercial banks, and government-sponsored enterprises.

With respect to the relationships between and among actors, the discussion has concentrated on the amalgamation between state and corporate actors and how those relationships can be observed or studied. First, O'Reilly introduced the theoretical construct of state-corporate symbiosis to denote the nexus and convergences between leading firms and state agencies. Accordingly, he emphasized that state-corporate symbiosis emerges because the "interests and objectives of state and market have become progressively indistinct" (O’Reilly 2010: 203).

In the same vein, Tombs (2012) has argued that the continuous symbiotic relationship between corporations and the state takes form through, for example, out-sourcing, contracting, privatization, and the adoption of new regulatory regimes of deregulation, e.g., reduction of administrative burdens and financial bailouts. For Tombs, the symbiotic relationship between these actors is systematic given that corporations are legal figures that are created and regulated by the state. This means that the autonomy of corporations is never complete since "corporations always exist simultaneously 'inside' and 'outside' of state rules and institutions" (Tombs 2012: 173).

One of the complexities that emerge from the analysis of the symbiotic relationship between states and corporations involves the apparent legality of actions adopted by both parties. The point at issue here is that harm to society can be inflicted by actions or inaction (on the complicity continuum) cloaked in legality since states and corporations claim to act within the boundaries of the law. Critical criminologists have illustrated this point in the case of corporate donations to electoral campaigns by calling such donations legal bribes (Friedrichs 2004; Evertsson 2012, 2017). Friedrichs (2004: 134) and Evertsson $(2012,2017)$ argued that elected politicians deliver undue benefits to their financial supporters (which is illegal) who give them interested money (which is legal), and both parties escape prosecution. Indeed, empirical studies by Peoples and Sutton (2015) and Evertsson (2018) have found that in cases involving electoral financial contributions by corporations, there is observable collusion caused by expected reciprocity originating from a conflicting symbiosis between both parties. Thus, state actions/inaction may result in inconsequential laws, regulations and controls that directly benefit corporate electoral donors. Another issue that has received attention in the state-corporate crime literature is the multidimensional role of the state and corporate actors. The concern here is that the symbiosis between such actors increasingly blurs because the players of these roles can easily switch positions. In this respect, Bradshaw (2015) argued that revolving doors normalize deviance among members of industries and agencies responsible for regulating and controlling these industries.

Second, the study of the symbiotic relationship between states and corporations has focused on examining national and transnational cases. Lasslett (2010: 227) has called researchers to go beyond the scholarly orthodoxy that focuses the analysis on state-corporate crime topographies as they "only help us to identify specific forms and exchanges that are of a particularly criminogenic character, they do not help us to understand the substantive social forces that inform these immediate perceived realities." While Lasslett (2010) proposes to address this issue by adopting the classic Marxist methodological approach to study state-corporate crime, Whyte (2014) has suggested that the analysis of 
state-corporate crime should scrutinize processes of capital accumulation that emerge from states' regimes of permission. This seeks to go beyond temporal observations or the study of moments of rupture, which are often documented in case studies that illustrate only regulatory collusion or regulatory failure.

\section{Previous Research}

This section presents the principal studies of state-corporate crime available in the literature. Two thematic issues are discussed, namely, (1) regulations and controls and (2) the symbiosis between public sector and private sector actors. The available research will be presented at national and transnational levels.

Turning first to national studies on state-corporate crime, scholarly studies have examined how regulatory frameworks and inspections are established to control commercial, financial, and operational activities of national and transnational corporations. Several case studies are worth noting. For example, an Indian case study conducted by Rawlinson and Yadavendu (2015) revealed the lack of regulations on the operations of multinational pharmaceutical companies that conduct the offshoring of clinical human trials. A Tasmanian case study documented by Green et al. (2007) illustrated the problem of regulatory capture of the forest authority that facilitated illegal logging in this territory. An American case study recorded by Leighton (2016) revealed the regulatory and bureaucratic failure at the congressional, federal, and state (Georgia and Texas) levels that lead to mass salmonella poisoning in the products produced by the Peanut Corporation of America (facility Blakely, Georgia). A Dutch case study conducted by van den Heuvel (2005) explained the emerging of cartel practices and the lack of monitoring during the construction of the Schiphol Train Tunnel.

Studies of TNC have demonstrated a similar focus. For example, Rothe and Ross (2010) studied the case of private military contractors (PMC) of the British and American governments who operate in disorganized environments, i.e., usually in internal conflicts such as Angola, Congo, Sierra Leone, Afghanistan, Iraq, and Equatorial Guinea. In this context, although the anomic conditions prevail, the PMC ignore international regulations. The situation turns even more complex when contracting governments (England and USA) relax their own audits and controls over the PMC. As this happens, it is evident that the PMC evade prosecution. Welch (2009), who takes a similar approach, has argued that the shortcuts in regulations and controls can be originated in the dispersion of state power, thus facilitating impunity or at least reducing the likelihood of prosecution. Quoting Peter W. Singer, Welch states “[t]hey simply didn't have enough eyes and ears watching what was going on... they seemed to show no interest in using the sanctions they had" (Welch 2009: 357). In another study of British PMC, Whyte (2003) argued that new forms of privatization have facilitated the retreat of the state from key military activities and the adoption of new forms of (re)regulation of PMC that have resulted in the diffusion of (legal) accountability.

The studies reported above indicate that the lack of regulations and the weak controls endorse state-corporate crime nationally and transnationally. In these investigations, scholars have examined various regulatory frameworks and/or pieces of legislation that affect a single corporation or industry. However, there are no studies that explore the role of a single regulation within various economic sectors and corporations. This inquiry addresses this gap in the literature by examining the following question. 
Research question 1:

How do TNC address national tax frameworks in the different countries of incorporation?

Beyond the issue of legality and control, scholars have also conducted local studies that examine the symbiotic relation between corporations and government officials. A German case study reveals the symbiosis between the family company Topf \& Söhne and the Nazi regime during the Holocaust, as this firm, which produced crematory ovens, was one of the providers of the ovens used in the concentration camps. van Baar and Huisman (2012) disclosed that this company was inspired by anti-semitic ideas and thus sought to profit as the Nazi regime was its primary customer. An American case study conducted by Finley and Esposito (2014) examined the case of the National Security Administration (NSA) and its relationships with Verizon, Google and other American telecommunication companies. They claimed that large revenues from contracts with the NSA motivated these corporations to conduct illegal surveillance, while the NSA argued that the use of excessive secrecy was essential for national security. Regardless that illegal surveillance constitutes a violation of international treaties, those who unveiled this abusive practice were indicted under the American Espionage Act and their allegations were dismissed.

The issue of symbiotic relationships between TNC and state actors has also been included in the research agenda of state-corporate crime scholars. Similarly, regarding the analysis of PMC, most studies adopt an industry approach. The concept of a criminogenic industry is discussed in Bradshaw's study of the oil industry, wherein she decided to "move beyond isolated case studies of state-corporate crime to create a systematic understanding of how the type, severity and frequency of harms vary among industries across time" (Bradshaw 2015: 379). She claims that the normalization of deviance within this industry is caused by the revolving door between legislators and corporate leaders who seek to tailor the environmental legislation, as well as the royalty's legislation, the energy legislation, the regulatory oversight, and the offshoring-exploitation legislation, and weaken controls by means of lobbyist advice, corporate campaign contributions, and bribery. In another study, Kramer (2013) suggests that ideological propaganda seeks to legitimize and normalize corporate practices that create pollution and affect the environment. He concurs with the argument of Washington and Cook, who suggest that " $[t]$ heir goal is to convince the public and the media that there are sufficient grounds not to take the action recommended by the consensus position of mainstream science" (Washington and Cook 2011: 43 quoted by Kramer 2013: 165). Kramer argues that conspiracy theories, fake experts, cherry picking data, and logical fallacies have been used to delegitimize dissenters.

More recently, Bernat and Whyte (2017) advanced the research agenda on the issue of symbiosis between states and corporations by studying the process of capital accumulation. These scholars examined two specific events, namely, the sinking of the oil tanker the Prestige in Galicia in 2002 and the killing of 24 Chinese migrant workers at Morecambe Bay in the northwest England in 2004, and found that state-corporate crimes do not only occur because of regulatory failure or the inaction of state officials, but they also occur when the "architecture of power in which states guarantee corporations various privileges and infrastructural capacities" is dominant (Bernat and Whyte 2017: 84). Furthermore, they suggest that in capitalist social orders the state creates and facilitates regimes of capital accumulation that are realized by corporations. This new approach to the study of state-corporate symbiosis points to the need to explore how regulatory frameworks aid corporations to accrue capital through different means. Whereas this inquiry addresses the issue of taxation of TNC, I seek to answer the following question. 
Research Can symbiosis between the state and TNC result in tax aid that

question 2: facilitates capital accumulation?

\section{Data Used in the Analysis}

The research tradition in state-corporate crime has been to conduct qualitative case studies based on data collected through interviews and diverse secondary materials, such as media reports, official documents, non-governmental organizations reports, and public hearings (for more details see Rothe and Kauzlarich 2016, chapter 3). In this study, I relied on two administrative decisions issued by a supranational authority. In 1940, Edwin Sutherland introduced the use of administrative decisions to the study of white-collar crimes; however, this type of data has rarely been used in state-corporate crime studies. In his pioneering study on white-collar crime, Sutherland (1940 [1983]) revised the decisions made in administrative agencies (822 decisions) and criminal courts (158 decisions) against the largest 70 manufacturing, mining, and commercial corporations in the United States.

In this inquiry, I turned to the European Commissioner for Competition (ECC) and examined the archive of administrative decisions regarding tax issues. One of the tasks of the ECC is to guarantee that tax rulings of member states do not result in decisions that selectively advantage multinational companies (Article 107 of the Treaty on the Functioning of the European Union). Tax rulings are comfort letters that specify how corporations can calculate their taxes in the country of incorporation. Since 1995, the ECC has issued 74 decisions on tax rulings that involved several TNC and the tax authorities of 17 European territories (Austria, Belgium, Denmark, France, Finland, Germany, Ireland, Italy, Luxembourg, Malta, the Netherlands, Poland, Portugal, Spain, Sweden, and the United Kingdom; European Commission Competition 2017).

This study is based on two of the most recent decisions of the ECC, namely, the Commission Decision of 21.10.2015 on state aid SA. 38374 that relates Starbucks with Belastingdienst (Dutch tax administration) and the Commission Decision of 21.10.2015 on state aid SA. 38375 that relates Fiat Automobiles with Administration des contributiones directes (Luxembourg tax administration). These decisions were chosen because they address companies that operate in different economic sectors but are involved in the same type of practice/process, i.e., transfer prices. These considerations seek to address Whyte's concern regarding the study of the process of capital accumulation rather than the study of individual cases. In the next section, the tax rulings in favor of Starbucks and Fiat are presented along with the administrative decisions reached by the ECC with respect to each case.

\section{Case 1: Starbucks and the Dutch Tax Administration}

The Starbucks group is an American conglomerate incorporated in Seattle that is dedicated to purchasing, roasting, and selling special coffee/tea/other beverages, food, and coffee handcraft in 65 countries. In 2014, the ECC launched an investigation to determine whether the Dutch tax administration had granted special advantages to the companies of the Starbucks group incorporated in the Netherlands. The decision of the ECC involves the following corporations operating in European territories: 
- ALKI LP (hereinafter ALKI) is incorporated in the United Kingdom and is owner of all intellectual property rights of the Starbucks trademark, Starbucks shop formats, and Starbucks corporate identity.

- Starbucks Coffee EMEA BV (Starbucks Coffee) is incorporated in the Netherlands and operates, on behalf of ALKI, as the allocator of the intellectual property rights to developers of Starbucks shops.

- Starbucks Manufacturing EMEA BV (Starbucks Manufacturing) is incorporated in the Netherlands and is responsible for roasting coffee outside the United States (US) and for selling roasted coffee to Starbucks shops.

- Starbucks Coffee Trading SARL (Starbucks Coffee Trading) is incorporated in Switzerland and is the only provider of green coffee beans to Starbucks Manufacturing.

\section{The Tax Ruling Approved}

On 28 April 2008, the Dutch tax administration approved an advanced pricing agreement that was initiated by Starbucks' tax advisor to determine Starbucks Manufacturing annual income tax liabilities in the Netherlands for a binding period of 10 years (2008-2018). The agreement assesses the manufacturing costs following the principle of arm's length remuneration, which is a transfer price among various parts of the same corporate group. The transactional net margin method (TNMM) was used to estimate the manufacturing cost. This method requires an indirect cost estimation be made based on a market comparison, which, in this case, included twenty global competitors of Starbucks. Starbucks' tax advisors claimed this method "is less affected by transactional differences and functional differences, as in the case with measures employed in standard traditional methods" (Commission decision 2015a: 10). The manufacturing cost includes all personal costs (manufacturing and sales), production equipment costs (depreciation), and plant overhead but excludes the cost of raw materials (coffee beans), and royalties for intellectual property rights. Starbucks' manufacturing costs were set at 9-12\% after risk adjustments.

\section{Decision 38374 of the ECC}

The ECC determined that the price transfer method, i.e., the TNMM, used by Starbucks Manufacturing and some of the costs associated with the intra-group transactions, such as manufacturing costs, coffee bean costs, and royalty payments, were not calculated in accordance with the OECD transfer price guidelines. According to the ECC, the TNMM should only be used when it is difficult to estimate the real cost of the intra-companies' transactions, which seems not to be the case for Starbucks Manufacturing. The ECC asked the Dutch tax administration to explain why they approved the use of this methodology. They replied,

[T]he Dutch tax administration always begins its investigation into the transfer process from the perspective of the methods used by the taxpayer... the Netherlands does not apply a 'best method-rule.' This starting point has resulted in the acceptance of the transfer price with the profit level indicator proposed by Starbucks Manufacturing EMEA BV (Commission decision 2015a: 45).

In addition to the use of the TNMM, the ECC considered that there were various mistakes in the calculations of the manufacturing costs. The market comparison of the manufacturing costs should not be expressed as a (single) mean value, but must be specified by 
quartiles considering the variations in operational risks. This specification seeks to attach the manufacturing price to the operation risk of the respective economic sector. In the case of Starbucks, the initial median manufacturing cost was $7.8 \%$. However, it was then inflated to between 9 and $12 \%$ even though the operational risk for this industry is low. Considering the level of operational risk, the final estimation of the manufacturing costs should have moved in the opposite direction, i.e., it should be lower than the median costs. The ECC found that ignoring the operational risk and the benchmark price per quartile affects the reliability of the estimations. In fact, the real manufacturing costs of Starbucks Manufacturing were lower than the annual costs calculated using the TNMM. Calculations for the operational years 2006/2007 and 2007/2008 were provided by Starbucks Manufacturing at the request of the ECC.

With respect to the cost of the green coffee beans sold by Starbucks Coffee Trading to Starbucks Manufacturing, the ECC found that the inter-company price was inflated to reduce the taxable base in the Netherlands. The investigation reported that between 2005 and 2010 the green beans sold by Starbucks Coffee Trading represented an average markup cost of 3\%, while between 2011 and 2014 the mark-up on cost of the green beans rose to $18 \%$. When asked about this increase, Starbucks Coffee Trading explained that originated in the introduction of the Coffee and Farmer Equity (C.A.F.E.) practices program that supports farmers in Costa Rica. However, as the cost of this program was, on average, $0.5-1 \%$ of the cost of the green beans purchased by Starbucks Coffee Trading, the ECC requested historic transfer pricing documentation to assess this issue. That said, this document was not supplied, but rather, an ad hoc transfer pricing report was submitted. The ECC found that the information provided in the ad hoc report and the information provided in the C.A.F.E. program were inconsistent. In the ad hoc report, the average markup on product costs was $12 \%$ (9-21\%), while in the C.A.F.E. program, it was $4.2 \%(1.4-9.9 \%)$.

The last conflicting issue in the tax ruling is related to the payment of royalties for the use of intellectual property rights, specifically, trademark, shop format, and coffee knowledge. In the tax ruling, it was stated that the three royalty payments made by Starbucks Manufacturing to ALKIP are taken from the residual profit pool and calculated as a predetermined percentage. The trademark royalties are paid on a digressively reduced rate from $65-70 \%$ in 2002 to $0.5-1 \%$ in 2010 . The business format royalties were calculated as a digressively reduced rate from $70-75 \%$ in 2002 to $0.0-0.5 \%$ in 2010 . With respect to coffee knowledge, a permanent royalty of $70-75 \%$ is paid. However, the ECC found several inconsistencies regarding the payment of the last type of royalty. First, the coffee knowledge royalty should not be paid by Starbucks Manufacturing because this company does not exploit the property rights of the roasting process on the market. The roasted coffee produced by Starbucks Manufacturing is only sold to Starbucks' shops and then to the customers. Second, Starbucks Manufacturing argues that they pay coffee knowledge royalties to ALKI when outsourcing the roasting of coffee to unaffiliated companies. However, unaffiliated manufacturers do not exploit the intangibles in the market as they supply the products back to Starbucks Manufacturing. A market examination conducted by the ECC demonstrated that none of the companies in the sector (e.g., Nestlé, Melita, Dallmayr) pay royalties when outsourcing the roasting of coffee. Third, ALKI does not play any role in the allocation and collection of royalties, as Starbucks Coffee is the company that identifies and grants the use of intellectual property rights. The ECC requested additional information on the operation of ALKI and found that ALKI does not have any employees on its payroll. However, Starbucks Manufacturing argued that they pay a temporary employee to provide managerial support to ALKI, while the operational capacity is provided through employees of the Starbucks group. The ECC found this 
argument to be unconvincing (Commission decision 2015a, p. 76). Finally, and foremost, because the royalty paid for the coffee roasting manufacturing is not originated in a contractual agreement, it is generated without legal substance by Starbucks Manufacturing.

Based on the above considerations, the ECC concluded that the Dutch tax administration granted a tax agreement that is contrary to European law and resulted in a lowering of Starbucks' tax liability in the Netherlands. The ECC ordered the Dutch tax administration to estimate and recover the unpaid taxes from Starbucks Manufacturing. The amount preliminary established to be repaid was between $€ 20$ and 30 million.

\section{Case 2: Fiat and the Luxembourg Tax Administration}

In 2010, the ECC initiated an ex officio investigation to examine the tax ruling practice adopted by the Grand Duchy of Luxembourg. The ECC solicited information on the legal principles and national rules that bind the Luxembourg tax administration when issuing tax rulings, the procedure to obtain a tax ruling, the information that the tax payer must submit to apply for a tax ruling, and a complete list of the 2010 tax rulings issued. This request was never met, nor were responses received to two additional letters issued in 2011 and 2012. On 19 June 2013, the ECC sent a new letter that was partially answered on 30 August 2013. In this response, the Luxembourg tax authority provided general information on the national tax regulations, but delivered no tax rulings. Moreover, the Luxembourg tax authority expressed doubts regarding the legal basis of the ECC to invoke a demand for such information. However, after a new request, the Luxembourg tax authority submitted 22 tax selected rulings issued between 2010 and 2013, claiming that this information was "representative of the Luxembourg tax ruling practice" (Commission decision 2015b: 3). In those rulings, the names of the tax payers were redacted because of the secrecy provision of the Luxembourg law. On 11 June 2014, the ECC opened an investigation against a company known as FFT. In the same opening decision, an information injunction decision was issued to the Luxembourg tax authority requesting, within 1 month, all documents, data, and information regarding the tax ruling granted to FFT. By a letter dated 14 July 2014, the Luxembourg tax authority refused to provide the requested information. On 14 August 2014, the ECC again demanded the information, invoking Article 6a of Regulation (EC) No. 659/1999. On 3 September 2014, the Luxembourg tax authority responded and confirmed the identity of FFT as Fiat Finance and Trade Ltd. On 17 October 2014, the opening decision was published in the Official Journal of the European Union.

The decision of the ECC involves the Fiat group, an Italian conglomerate that conducts industrial and financial services in the automobile sector in more than 140 countries. The following companies of the group were involved in the investigation conducted by the ECC:

- Fiat group (Fiat) is incorporated in Italy, and at the time of the tax ruling, it included Fiat S.p.A. and all companies controlled by Fiat S.p.A.

- Fiat Finance S.p.A. (FF) is incorporated in Italy, and at the time of the tax ruling, it provided treasury functions for the entire group; on 12 October 2014, FF merged with Fiat Investments N.V. and became Fiat Chrysler Automobiles N.V.

- Fiat Finance and Trade Ltd. (FFT) is incorporated in Luxembourg and manages treasury functions for the European based companies of the group.

- Fiat Finance North America (FFNA) is incorporated in Italy and manages treasury functions for the American based companies of the group. 
- Fiat Finance Canada (FFC) is incorporated in Italy and manages treasury functions for the Canadian based companies of the group.

\section{The Tax Ruling Approved}

On 3 September 2012, the Luxembourg tax authority approved a tax ruling in favor of FFT. The ruling granted the use of the TNMM to estimate FFT's net profit allocation, which in turn is used to determine the annual corporate tax liability of this company for a binding period of 5 years (2012-2016). FFT's tax advisor claimed that the TNMM is the most adequate method to conduct the estimations because FFT is a company that only performs financial services for Fiat, and accordingly, an estimation of the profit based on a market comparison is appropriate. The net profit allocation was calculated in four steps and considered two types of remunerations, namely, for risk and functions. In step one, the capital at risk was obtained by aggregating the operational risk ( $€ 0.9$ million), the counterpart risk (€2.7 million), the credit risk ( $€ 24.9$ million), and the exchange rate risk (valued at zero), all of which were calculated using the Basel II Framework. The estimated value of the minimum capital at risk was set at $€ 28.5$ million. In step two, the capital used to perform the treasury functions was obtained by adding the minimum capital at risk ( $€ 28.5$ million), the capital needed for supporting the financial investments of the nonEuropean subsidiaries FFNA and FFC (estimated at $€ 165.2$ million), and the capital needed to support the functions performed (estimated at $€ 93.8$ million). The FFT total capital was valued at $€ 287.5$ million. In step three, the remuneration of the minimum capital at risk, i.e., the expected return pre-tax, was estimated using the capital asset pricing model (CAPM), as follows:

$$
\text { Expected return pre-tax }=(\text { risk-free rate }+(\beta \times \text { equity risk premium })) /(1-\text { tax rate })
$$

The values of three out of the four parameters used in the CAPM were obtained from the market. The risk-free rate used was $2.85 \%$, which was based on a 10 -year German government bond (Bundi), the equity risk premium for Luxembourg was $5 \%$, as reported on the Damoradan website, and the Luxembourg tax rate $(28.8 \%)$. The beta $(\beta)$, i.e., return on equity, was obtained from the average of the betas of 66 companies performing financial services (source: Damoradan website). The beta value for FFT was estimated to be 0.29. After applying the above formula, the expected return pre-tax obtained was $6.05 \%$. In step four, the overall remuneration of FFT was calculated by adding the risk remuneration and the functions remuneration. The risk remuneration was the result of multiplying the minimum capital at risk ( $€ 28.5$ million) by the expected return pre-tax $(6.05 \%)$. It was calculated to be $€ 1726$ million. The functions remuneration was obtained by multiplying the capital needed for backing the functions ( $€ 93.7$ million) by the market rate for short term deposits $(0.87 \%)$ based on the Euro OverNight Index Average, which was estimated to be $€ 816$ million. The final taxable base was valued at $€ 2542$ million.

\section{Decision 38375 of the ECC}

The ECC expressed doubts regarding the legality of the tax ruling granted in favor of FTT. First, the tax ruling was set to accept an annual pre-determined fixed tax base (€2542 million) during the period of validity of the ruling decision (2012-2016), which, according to the ECC, ignores operational and financial changes in FFT activities. Second, the ECC considered that the TNMM is not the most appropriate method to calculate the 
liability tax base because there are other companies in the same group (e.g., Chrysler) that perform similar activities. Therefore, it is not necessary to use indirect methods of comparison such as the TNMM. The ECC determined that the comparable uncontrolled price (CUP) method would be the preferred approach in this case, as this method estimates the pricing transactions based on data from companies of the same corporate group. The ECC observed that after reviewing the 21 other rulings summited by the Luxembourg tax authority, they (the ECC) found that this authority behaved inconsistently given that they had approved the use of the CUP method in two other rulings related to treasury activities. Specifically, the ECC noted that

[c]ontrary, to those two rulings, the CUP method was not applied in the contested tax ruling because FFT's tax advisor considered the TNMM as the most appropriate method based on the fact that the "TNMM looks adequate" (Commission decision 2015b: 69).

Third, the ECC questioned the application of the CAPM as an appropriate method to determine the return on capital, which gave rise to various issues. First, the CAPM is used to estimate the return on regulatory capital rather than the return on capital. This inconsistency emerges because FFT uses the Basel II Framework to estimate the return on regulatory capital although FTT is not a regulated entity, and as such, the use of such a framework has not been approved by a financial institution regulator. The ECC estimated that this methodological inconsistency "results in a lowering of FFT's taxable remuneration in Luxembourg by a factor of ten" (Commission decision 2015b: 54). Furthermore, the ECC noted that several of the 66 companies included in the estimation of the beta "are clearly inadequate for estimating average regulatory capital in the industry ... since ... those companies are not regulated entities falling under the Basel Frameworks" (Commission decision 2015b: 55). Additionally, the beta value of 0.29 used by FFT corresponds to the lower quartile of the market comparison without any justification. The OECD transfer price guidelines stipulate that the median of the beta values of comparable companies should be used in the CAPM estimations. If the market comparison proposed by FTT would have been valid, then the correct beta value should have been 0.64 rather than the 0.29 suggested by FFT's tax advisor (Commission decision 2015b: 63). Finally, the ECC argued that a correct application of the Base II Framework requires a market estimation of the risks of the intra-group loans, i.e., counterpart risk, credit risk, and exchange rate risk, despite FFT's claims that this risk is limited or nearly zero. Using the average European risk over assets of banks as a relevant comparator, the ECC estimated that the minimum capital at risk should be approximately $€ 427$ rather than the $€ 28.5$ million reported by FFT's tax advisor.

For the ECC, the contested tax ruling grants a selective advantage to FFT that results in lowering FTT's tax liabilities in Luxembourg. This selective advantage is financed through state resources, thus distorting competition and impacting the intra-EU trade. The ECC states that Luxembourg shall recover the incompatible and unlawful aid granted to FFT, and if FFT is not in the position to pay, then Fiat Chrysler Automobiles N.V. should restore the unpaid tax liabilities on the condition of a successor of the Fiat S.p.A. The amount to recover is estimated to be between $€ 20$ and 30 million. 


\section{Analysis}

The cases examined in this study illustrate how TNC trespass tax regulations aided by government officials. Using the nomenclature suggested by Friedrichs and Rothe (2014), it can be argued that these cases are examples of corporate-state crime, given that TNC take the initiative to transgress tax laws and regulations. However, it must be emphasized that corporations do not act alone. Starbucks and Fiat were assisted by their tax advisors in submitting their requests to the authorities, even though the ECC did not sanction them. Nonetheless, this is not an indication that tax advisors are not responsible for the transgressions of their clients. In a previous cross-national study on tax avoidance in OECD countries, the author found that accounting firms who also provide legal tax advice are behind the adoption of the tax avoidance schemas of their clients (Evertsson 2016a). This point revisits the issue of the qualifications of the public sector and private sector actors who are involved in this type of crime, as suggested by Friedrichs and Rothe (2014). I propose to include tax advisors in the group of private sector actors/perpetrators, because they are among the intellectual actors responsible for this type of transgression. By adopting this approach, I seek to enlarge the profile of state-corporate/corporate-state offenders by including tax advisors in the list of criminogenic industries because their explicit actions bring about crimes against global and national tax regulations that harm society at large around the world.

One issue that emerged from this study, which is rarely discussed in cases of statecorporate/corporate-state crime, is the structure of TNC. In the case of Starbucks, the ECC questioned the role of the UK subsidiary ALKI as this company was set up to receive payment of intangibles. Payment of intangibles is a conventional practice of tax avoidance used to increase costs in intra-group transactions through operating artificial companies, also known as paper companies (Nedham 2013). Thus, it can be assumed that ALKI was not established to sell more coffee in European Starbucks shops but to reduce tax liabilities in the Netherlands. This is an illustration of the argument made by Alfred D. Chandler, Professor in Business History at Harvard University, who claims that "the structure follows the strategy" (Chandler 1962 [1998]). As this happens and to use an analogy, one can argue that the criminal structure follows the criminal strategy designed to pay less in corporate taxes. A prior study in which I addressed crimes of globalization produced a similar result. In particular, I examined the structure of IKEA, a former Swedish TNC that became a Dutch charity organization to avoid paying taxes in Sweden and other countries of incorporation. After close analysis of this TNC, I found that IKEA had adopted the most stringent tax avoidance practices ever exhibited, including transformation of the ownership structure of the entire global conglomerate as well as the financial, commercial, and operational structures of the company's international operations (Evertsson 2016b). One can even argue that this strategy is an extremely wellorganized approach for conducting tax avoidance on a global scale.

Beyond the issue of structure, the ECC also unveiled an apparent symbiotic relationship between tax authorities and the TNC studied herein. This conclusion emerges when analyzing how the tax operation is endorsed by tax authorities. In the description of the cases studied, it was revealed that these companies used the same indirect method (TNMM) to estimate tax liabilities, claiming that it is better to use market information than intra-group data. However, the decisions of the ECC questioned the application of undue regulatory frameworks since tax authorities accepted the proposed methods of the corporations to estimate tax liabilities without deeply scrutinizing the criteria or the methods used. For example, the Dutch tax authority argues that they do not use a best-method rule (in the case of Starbucks; Commission decision 2015a: 45), and the Luxembourg tax authority argues 
that the TNMM appears to be adequate (in the case of Fiat; Commission decision 2015b: 69 ). This not only undermines the capacity of control of these tax authorities, but it denotes favoritism and inconsistent behavior in the application of the law. Kauzlarich et al. (2003) have claimed that this is an explicit act of omission that has been illustrated in various studies of corporate-state/state-corporate crime and that it emphasizes that weak controls facilitate the emergence of this type of transgression (van den Heuvel 2005; Rothe and Ross 2010; Welch 2009; Whyte 2003).

In view of the evidence, one can argue that, this observable symbiosis emerges from the implementation of administrative regulations that were adopted through tax rulings based on illegal decisions. Along with Tombs (2012), I would argue that this suggests that the regulatory system is benefitting those corporations that are seeking to enlarge the capital accumulation of the ownership of these organizations. Thus, contrary to the case studies reviewed in this article where state-corporate crime scholars have suggested that this practice emerges because of a lack of regulations (Rawlinson and Yadavendu 2015; Green et al. 2007; Leighton 2016), the two cases examined herein indicate that Starbucks and Fiat use tax regulations in a manipulative way (research question 1). The manipulative use of the tax law, as illustrated here, reflects the unlimited influence of powerful actors who seek to profit at any cost and the weakness of laws that prevent the criminalization of powerful perpetrators, which is evidenced by the fact that they are not indicted in criminal courts (Kramer et al. 2002: 266).

Based on this verifiable symbiotic relationship, the ECC advanced the argument that these organizations received aid from their respective tax authorities to reduce their tax liabilities (research question 2). Why is a national authority interested in helping foreign companies? Is this a situation that benefits society? Elsewhere, I have argued that tax incentives offered to international investors are the result of re-writing the rules of the economy in favor of the powerful (Evertsson 2016b). The fact is that competitive tax territories strive to provide international investors with favorable conditions and even secrecy at the expense of their own citizens. As a result, such investors provide minimal economic and societal benefits, whereas corporations enlarge their coffers. However, it remains inexplicable that tax authorities, which play the role of collecting taxes, grant tax benefits to certain corporations.

Since the material used in this study (administrative decisions) does not provide grounds for additional clarifications beyond those discussed above, one can propose possible explanations that must be tested in future studies. For example, relationships between tax advisors and tax authorities could be elucidated. Bradshaw's arguments regarding revolving doors and criminogenic industries may be relevant in this context. The issue is that tax officials are an attractive labor force for tax advisory firms that seek to strengthen their links with tax authorities. One possible way for tax advisory firms to gain access to responsible individuals in decision-making processes is by hiring former employees to allow for the exploitation of relationships between these ex-employees and their former peers. Former employees are also aware of internal controls and how they are applied; therefore, their knowledge and experience are highly desirable. Another possible alternative is to internally examine tax authorities to discover corporate wrongdoing (Palmer 2012). This issue, of course, turns attention to these organizations to elucidate causes of the problem in question and possible policy actions. In this terrain, the issue of corruption cannot be dismissed. In this matter, explanations of bribery and legal bribery could provide interesting answers because inquiries should address not only employees who sign tax agreements but also those responsible for leading organizations and delineating organizational policies. For example, evidence collected in the case of the Luxembourg tax authority clearly points to certain internal failures at the top level of the organization and even at the top political level (given that secrecy for investors is guaranteed in this European territory) that will be interesting to explore in greater detail. 


\section{Conclusions}

Despite the tremendous results of the investigations conducted by the ECC, it is important to remember that this European authority is not an instance of supranational control or permanent inspection. The ECC conducts random and selective investigations as stipulated in Article 107 of the Treaty of the Foundation of the European Union. The ECC is not searching for economic crimes; rather, its role, among others, is to prevent state aid to corporations through favorable tax rulings. In other words, the ECC does not examine whether taxes are being paid in the countries of consumption, but if tax rulings are granting advantages to one company over its competitors. The ECC uses the OECD tax guidelines, which were introduced to prevent double taxation of corporations that operate globally by allowing the use of direct and indirect methods for estimating tax liabilities such as TNMM. Why should TNC use different methods than those available to national companies? This is a problem that must be revealed and addressed considering that global tax frameworks are used to increase capital accumulation. Global tax guidelines promote corporate expansion while renegotiating the national tax frameworks and imposing tax agreements that favor TNC.

Although taxation is not a process of capital accumulation, this inquiry demonstrates that TNC view taxation as capital accumulation considering that taxes are reduced to increase corporate profits. However, taxes are not costs that can be optimized as Starbucks did, nor are they fixed amounts that can be negotiated ahead of the real operation as in the case of Fiat. Taxation is a governmental function that seeks redistribution and compensation for the provision of state services. This study revealed that governments made decisions that undermine their own interests when granting (favorable) tax rulings. Although this sounds contradictory, it illustrates the symbiosis between TNC and tax authorities, thereby making it difficult to distinguish the interests of the parties involved. Symbiosis is not only achieved by legal contracts or through favorable regulatory frameworks, as demonstrated in previous studies but also through the manipulative use of regulations and weak controls.

Open Access This article is distributed under the terms of the Creative Commons Attribution 4.0 International License (http://creativecommons.org/licenses/by/4.0/), which permits unrestricted use, distribution, and reproduction in any medium, provided you give appropriate credit to the original author(s) and the source, provide a link to the Creative Commons license, and indicate if changes were made.

\section{References}

Bernat, I., \& Whyte, D. (2017). State-corporate crime and the process of capital accumulation: Mapping a global regime of permission from galicia to morecambe bay. Critical Criminology, 25(1), 71-86.

Bradshaw, E. A. (2015). "Obviously, we're all oil industry": The criminogenic structure of the offshore oil industry. Theoretical Criminology, 19(3), 376-395.

Chandler, A. D. (1962 [1998]). Strategy and structure: Chapters in the history of the American industrial enterprise. Cambridge, MA: MIT Press.

Evertsson, N. (2012). Electoral donations as legal bribes: Evidence from a survey of private corporations in Colombia. International Journal of Criminology and Sociology, 1, 162-175.

Evertsson, N. (2016a). Is the top leadership of the organizations promoting tax avoidance? Journal of Financial Crime, 23(2), 273-288.

Evertsson, N. (2016b). Corporate tax avoidance: A crime of globalization. Crime, Law and Social Change, 66(2), 199-216.

Evertsson, N. (2017). A nested analysis of electoral donations. Journal of Mixed Research Methods, 11(1), 77-98. 
Evertsson, N. (2018). Corporate donations to electoral campaigns. The current state of affairs. In J. Mendilow \& E. Phélippeau (Eds.), Handbook of political party funding. MA: Edward Elgar Publishing, Northampton (forthcoming).

European Commission Competition. (2017). State aid. Tax rulings. http://ec.europa.eu/competition/state_ aid/tax_rulings/index_en.html. Accessed 23 March 2017.

Finley, L., \& Esposito, L. (2014). "Digital blackwater": The national security administration, telecommunications companies and state-corporate crime. State Crime Journal, 3(2), 182-199.

Friedrichs, D. O. (2004). Trusted criminals: White-collar crime in contemporary society. Belmont, CA: Wadsworth/Thomson Learning.

Friedrichs, D. O., \& Rothe, D. L. (2014). State-corporate crime and major financial institutions: Interrogating an absence. State Crime Journal, 3(2), 146-162.

Green, P., Ward, T., \& McConnachie, K. (2007). Logging and legality: Environmental crime, civil society, and the state. Social Justice, 34(2), 94-110.

Kramer, R. C. (1992). The space shuttle challenger explosion: A case study of state-corporate crime. In K. Schlegel \& D. Weisburd (Eds.), White collar crime reconsidered (pp. 212-241). Boston, NH: Northeastern University Press.

Kramer, R. C. (2013). Carbon in the atmosphere and power in America: Climate change as state-corporate crime. Journal of Crime \& Justice, 36(2), 153-170.

Kramer, R. C., Michalowski, R. J., \& Kauzlarich, D. (2002). The origins and development of the concept and theory of state-corporate crime. Crime \& Delinquency, 48(2), 263-282.

Kauzlarich, D., Mullins, C. W., \& Matthews, R. A. (2003). A complicity continuum of state crime. Contemporary Justice Review, 6(3), 241-254.

Lasslett, K. (2010). Scientific method and the crimes of the powerful. Critical Criminology, 18(3), 211-228.

Leighton, P. (2016). Mass salmonella poisoning by the peanut corporation of america: State-corporate crime involving food safety. Critical Criminology, 24(1), 75-91.

Michalowski, R. J., \& Kramer, R. C. (1987). The space between laws: The problem of corporate crime in a transnational context. Social Problems, 34(1), 34-53.

Nedham, C. (2013). Corporate tax avoidance by multinational firms. Strasburg: European Parliament.

O'Reilly, C. (2010). The transnational security consultancy industry. A case of state-corporate symbiosis. Theoretical Criminology, 14(2), 183-2010.

Palmer, D. (2012). Normal organizational wrongdoing. Oxford: Oxford University Press.

Peoples, C. D., \& Sutton, J. (2015). Congressional bribery as state-corporate crime: A social network analysis. Crime, Law and Social Change, 64(2-3), 103-125.

Rawlinson, P., \& Yadavendu, V. K. (2015). Foreign bodies: The new victims of unethical experimentation. Howard Journal of Criminal Justice, 54(1), 8-24.

Rothe, D. L., \& Kauzlarich, D. (2016). Crimes of the powerful: An introduction. New York: Routledge.

Rothe, D. L., \& Ross, J. I. (2010). Private military contractors, crime, and the terrain of unaccountability. Justice Quarterly, 27(4), 593-617.

Sutherland, E. H. (1940 [1983]). White collar crime: The uncut version. New Haven: Yale University Press.

Tombs, S. (2012). State-corporate symbiosis in the production of crime and harm. State Crime Journal, 1(2), 170-195.

van Baar, A., \& Huisman, W. (2012). The oven builders of the holocaust. British Journal of Criminology, 52(6), 1033-1050.

van den Heuvel, G. (2005). The parliamentary enquiry on fraud in the Dutch construction industry collusion as concept between corruption and state-corporate crime. Crime, Law \& Social Change, 44(2), $133-151$.

Washington, H., \& Cook, J. (2011). Climate change denial: Heads in the sand. London: Earthscan.

Welch, M. (2009). Fragmented power and state-corporate killings: A critique of blackwater in Iraq. Crime, Law \& Social Change, 51(3/4), 351-364.

Whyte, D. (2003). Lethal regulation: State-corporate crime and the United Kingdom government's new mercenaries. Journal of Law \& Society, 30(4), 575-600.

Whyte, D. (2014). Regimes of permission and state-corporate crime. State Crime Journal, 3(2), $237-246$.

\section{European Commission for Competition: Cases}

Commission Decisions of 21.10.2015 on state aid SA. 38374

Commission Decisions of 21.10.2015 on state aid SA. 38375 